\title{
History of Hospitality Laws - Do Islamic and South Asian Legal History Have the same Approach? (A Comparative Approach of Sharī'ah \& Law)
}

*Dr. Lutfullah

*** Farhad Nazir

\section{ABSTRACT:}

Respect for guests and visitors, indeed, always remain a common notion of civilized nations; existing on this earth since its inception. This peculiar characteristic, of course, differentiates human beings from animal where the previous are rightly called social animals. The South Asian countries i.e. Pakistan, India, Bangladesh and Nepal are not different in this regard. Their history is always remained a solid evidence of their generosity towards the guests and visitors. Being remained under the rule of the Great Britain, these countries have the same legal history and legal spectrum for dealing tourists and visitors. However, this similarity in terms of hospitality laws is also owing to the similar teaching of their corresponding religions. Findings show that Islam, Buddhism and Hinduism have some common teaching regarding the respect of guests. While having deep sentiments for religious teaching, the residents of such states want the inculcation of religious guidelines in their legal system. Islamic law offers a comprehensive guideline for hospitality comparatively to other religions. Being an Islamic country, it is supposed that such guidelines should be followed while framing legislation for hospitality and tourism. However, study shows that much work is not done yet in this regard. Content analysis technique of qualitative research has been followed in the present work for the investigation of the issue.

Keywords: Hospitality Law, Law, Legal System, Guests, Tourism, Islamic Law, South Asia, Sharī'ah.

\section{Introduction:}

Mankind in its journey towards humanity, indeed, has developed a social system for every member of society. This historical development distinguishes the civilized societies from the uncivilized societies, predominantly, those having no legislation for their inhabitants. Besides mankind, religion also plays its role in this connection. The religion of Islam, on the other hand, claims to be a "complete code of life" provides a comprehensive guidelines about travelers, guests and their hospitality by stating" Worship ALLAH and associate nothing with him, and to parents do good, and to relatives, orphans, the needy, the near neighbor, the neighbor farther away, the companion at your side, the traveler, and those whom your right hand possess. Indeed, ALLAH does not like those who are self-deluding and boastful". ${ }^{2}$ Moreover, the Arabic words, 'dayf'3 is used in the Holy Qurān for honoring and facilitating the

\footnotetext{
*Associate Professor (Law and Sharī'ah), University of Swat, KPK, Pakistan. Email: lutsaqib@gmail.com

${ }^{* * *}$ Lecturer, Tourism and Hospitality, Institute of Cultural Heritage, University of Swat, KPK.
} 
guests and their hospitality. Showing hospitality to guests is mentioned, too, on various occasion in the teachings of Haditth. For instance, the Hadìth, narrated by Abu Huraira(RA) states"... anybody who believes in ALLAH and Last Day should entertain guests generously, and should serve his guest generously by giving him his reward". These evidences from the Holy Qurān and Hadìth of the Holy Prophet (SAW) justify, though indirectly, the importance of hospitality laws in Islamic legal system. Having such importance in mind, the classical Muslim jurists have devoted a substantive part of their work to the importance of hospitality and its other related issues. These jurists include Imām al-Shawkānī ${ }^{4}$, Imām al-Kāsānn̄ ${ }^{5}$, Ibn Qudāmah al-Maqdisī̄ ${ }^{6}$, Abu alWalīd Muhammad ibn Ahmad ibn Rushd ${ }^{7}$, Imām Muhammad ibn Ahmad ibn Abī Sahal al-Sarkhas $\bar{i}^{8}$, and Ibn 'Ābidīn'. Among these jurists, the work of Imām Muhammad ibn Ahmad ibn Abī Sahal al-Sarkhasī is very comprehensive over the issue under investigation.

Of course, legislations and laws are of keen importance for social systems, therefore, it requires the universal acceptances and generality, predominantly, for phenomena like hospitality and laws relating to it. Considering this importance, various countries of the world have developed the hospitality laws for the best facilitation of the guests and hosts. The case of Pakistan is not different in this regard where "Hotel and Restaurant Act $1976 " 10$ is the only approved hospitality law, formulated in order to exercise various practices of hospitality over here - both in letter and spirit. However, this hospitality law is inconsistent with the principles of Islamic law envisaged for hospitality. Being an Islamic country, such inconsistency is against the basic ideology elaborated in the Objective Resolution, $1949^{11}$ and Constitution of 1973.

The relationship of hospitality with Islam is well addressed by researchers. The work of Mona Siddiqui can be cited, herein, as an example. ${ }^{12}$ She has elaborated a detailed ideological interpretation of hospitality in Islamic teachings. Marcus L. Stephenson ${ }^{13}$, on the other hand, has also offered a scholarly work, introducing new terminologies like "Islamic hospitality". ${ }^{14}$ Toshihiko Izutsu, another scholar of the field, has explained the philosophical importance of hospitality ethics described by Islam in the Holy Qurān. ${ }^{15}$

Like other research endeavors, the present paper has some inbuilt objectives followed in the whole structure. Firstly,to explore the existing laws on the subject of hospitality within the South Asia, specifically, in Pakistan. Here, at this level the historical perspective of such laws has been discussed with minute details. In addition, all relevant laws (related to discipline of hospitality and history of their legislation) are discussed. Moreover, the hospitality laws of South Asian countries are profoundly compared with that of Pakistani laws. Secondly, the present work offers suggestions for the inculcation of all those guidelines provided by Shari'ah for the development of hospitality policies. This approach may be rightly called Islamization of hospitality laws. Thirdly, to inculcate all these guidelines in the existing structure of hospitality legislation; in lining the contemporary hospitality laws with Sharīah. Fourthly, to recommend some proposals for future legislation in Pakistan over the subject. Fifthly, 
to know the historical hospitality perspective of Shari'ah and its contemporary position over the subject. Here at this stage, the work of classical Muslim jurists is extensively used.

The current research also has some intrinsic limitations. For instance, it is limited to hospitality laws' history of Pakistan, India, Nepal and Bangladesh. The findings, therefore, cannot be generalized for other regions. However, it doesn't mean, under any stretch of explanation, that the present work is not beneficial for other countries. The findings and conclusion, drawn herein, can be used for other regions in a generic way. Moreover, the Muslims countries, principally, those having the same political, social and geographical structure, as that of Pakistan and Bangladesh, can take more benefits comparatively to others. This characteristic, indeed, increases the viability of the present work for other countries - a clear picture of academic globalization.

\section{Methodology:}

Discourse analysis, a viable technique of qualitative research, has been used for the investigation of the issue under consideration. This form of technique extracts meanings from textual evidences, predominantly, when it comes to understand the societal laws on hospitality, their history and Islamic teachings - the prime locus of current study. Following this technique, the texts from the conventional and Islamic laws of hospitality are used extensively. Moreover, the elucidations of such laws have been done through their textual and contextual consideration for reaching to a universal meaning. The connectivity order (in research) is formulated by consulting the work of various scholars of the field. The study has made a significant use of secondary data, accessed from hospitality laws of South Asian countries and Islamic teachings. In the latter case, the work of classical Muslim Jurists is used exhaustively. For this, data has been collected from printed and online books, reputed journals, websites, magazines, newspapers and other relevant sources on the issue under investigation. Official websites of Government bodies and other relevant authorities are browsed to have relevant authentic data in hands. Translation and commentary (Tafseer) of Holy Qurān has been made from very reliable works.

\section{History of Hospitality Laws in South Asia (A Realistic Historical Approach):}

Current South Asian countries, besides Afghanistan, have been part of Indian SubContinent, shared some unique and alike hospitality characteristics; mainly due to cultural cohesion among inhabitants and religious harmony among these countries at that time. Owing to this fact, the countries like India, Nepal, and Bangladesh have celebrated hospitality values towards the visitors. The verse of Sanskirit ${ }^{16}$, herein, can be cited as an example i.e. "Mathr Devo bhavah Pithr Devo Bhavah Acharya Devo Bhavah Atithi Devo Bhavah" 17 meaning thereby "guests is like a God". ${ }^{18}$ The example of Buddhism - being practiced in the countries of Nepal and India, was, also not different in this regard; having historical hospitality perspective about the guests. Moreover, the e teachings of Buddha compelled (his followers) to show hospitality and charity to each other. ${ }^{19}$ The populous of these countries continued, of course, these historical hospitality values. They aligned their hospitality rules and regulation 
with their corresponding religious teachings - can be rightly called a natural dominant compulsion. Muslim countries (of the same region), on the other hand, including Pakistan and Bangladesh, followed the same approach towards the travelers and visitors, considering the guests or incoming travelers as blessings from the Almighty $A L L A H$. Moreover, their serving was considered a pious duty and a sacred obligation on the hosts - a phenomenon which could not be found in any other religion.

The current Republic of India, before independence from the British subjugation, possessed cultural, religions and lingual diversity. Even today the same situation could be found. Here also, hospitality for the guests and travelers was revealed in Dharmashalas ${ }^{20}$, meaning thereby to assist the travelers. ${ }^{21}$ In these Dharmashalas, the traditional touch of hospitality was offered to the guests, mainly, free of cost; and due care was extended to their horses or transport animals as well. This service to the guests, rather than a burden on the host, was considered an honor and, at the same time, opportunity to please God/Goddesses. A well-known maxim i.e. At thi/Mehman to bhagwan hota hai (Guests is the reflection of God) can be cited as an example of this approach. This maxim is the modified version of that Sanskrit verse mentioned earlier in this work. These theological and social amalgamations of hospitality were reason to float the hospitality and tourism logo of this country as "Incredible India" 22 . Besides the religious, social and traditional aspects of hospitality in India, the legal aspect was covered by a famous legal document i.e. the Sarai Act 1867. This law was kept operational for fulfilling the legal features, procedures and policies of hospitality even after independence from the British rule. No separate legislation was legislated for hospitality and, therefore, global change from tradition to industry was not accommodated in the legal spectrum. It is pertinent to mention that till now the same Sarai Act of 1867 is applicable in different states of India. In 1955, while following the global advancement in hospitality, Federation of Hotel and Restaurant Association of India (FHRAI) was structured to acknowledge the importance and promotion of hospitality industry in India. ${ }^{23}$ This association had considered the impact of globalization on hospitality; prepared the professionals in hospitality. This approach enabled the country to have, modern hospitality set of values and standards. ${ }^{24}$ Legal position, over the subject of hospitality in India, still stood on the Sarai Act 1867, and till the time of writing, there is no separate hospitality law in India, to address the modern hospitality, its practices, issues and challenges.

The country of Nepal, another icon of hospitality values, had opened formal ways for travelers in 1960s. ${ }^{25}$ Through this formal way the travelers were welcomed with traditional hospitality and lucrative comfort. Here as well, like India, one could sense the inclination of hospitality towards the religion and a pyramidal shift, at the same time, towards the modern practices. This country, as a home to world's highest summit-Mount Everest and the offshoots of range of Himalaya along with rich cultural heritage ${ }^{26}$, attracted the travelers. Nepalese people had offered this hospitality even in their family homes termed as "tea houses" 27 a phenomenon showed the cordial and passionate attitude towards the travelers. This passion and open heart- 
edness for the guests was the outcome of social and cultural values; inculcated in various maxims and proverbs over the importance of hospitality i.e. "Juna gharama athiti satkara hudaina, tyo ghara samasana saraha huncha.khalil Gibran" (The house in which the hospitality does not work is a shrine...). Obligation on hosts for catering and welcoming of the guests is discussed as "atithiharu svagatako bhoko huncha" (Guests are hungry of welcome). These maxims, and many others, urged every inhabitant to be humble, caring and regardful to the guests. These sayings, later on, became the legal foundation for the legislation, legislated on hospitality.

The legislative feature for hospitality of in Nepal was quite different from other countries of South Asia. Having said that, a rich legal system was introduced for the safety and protection of travelers; including, mainly "the Hotel, Lodge, Restaurant, Bar and Tourists Guide Rules, 1981", the Tourism Act, $1978^{28}$. The aim was to operationalize the visitor's management and issues effectively; as the country was receiving bulk of travelers. It is pertinent to mention that the domain of the Tourism Act 1978 was used to encompass the hospitality sector and its industrial practices.

The country of Bangladesh ${ }^{29}$, had a parallel history of hospitality as that of Pakistan. Here, too, the Sarai Act 1867 kept functional till 1982 when "The Bangladesh Hotel and Restaurant Ordinance, 1982" was added to the legal spectrum of the country. Essence of Asian hospitality, embeds with traditional values, was visible here; claimed to be excelling "Truly Asian Hospitality" ${ }^{30}$ Rank as one of Muslim Country ${ }^{31}$ in the global arena, however, amalgamation of western hospitality values were much visible. Owing to this fact, many rules of hospitality were inconsistent with that of Islamic law. ${ }^{32}$ Because of this, Islamic hospitality teachings were entirely ignored in the relevant laws i.e. "The Bangladesh Hotel and Restaurant Ordinance, 1982". However, the stakeholders of hospitality, predomina-ntly, the academicians were in favor of bringing the rules of Islamic law to the exis-ting system. ${ }^{33}$ Culturally, there exist some guidelines and compulsions where it is made obligatory to offer the guest something to eat and drink during every visit. ${ }^{34}$ It means that the religious obligations, about hospitality, have been followed at state level. Socially, the people of Bangladesh, too, are very much hospitable towards the guests. ${ }^{35}$

\section{History of Hospitality Laws in Pakistan (An Indigenous Approach):}

After getting independence from the Britain, Pakistan took a lot of time to legislate separate laws on hospitality. At that time, various British laws (legislated for former sub-continent) had been adopted on courtesy grounds with slight modifications. The case of hospitality laws was also not different in this regard, and the Sarai ${ }^{36}$ Act 1867 and "Hotel and Lodging -Houses Control Act 1950"37 were practiced in order to execute the practices of hospitality. These two Acts served as the legal resources for the visitors - the demand and supply side of hospitality.

The traditional aspect of hospitality, based on cultural values, was still being practiced since the independence. These cultural values had roots in diversified civilizations, embraced by the subcontinent for a long time. Despite these rich cultural values, the need of the time was to acknowledge the importance of hospitality not on cultural 
grounds but also on legal grounds. Moreover, it was also mandatory for meeting the global paradigmatic shift; ascribing the hospitality as an industry - having a lot of potentials for earning money.

Islam was officially recognized as "State religion" in the Constitution of $1973 .{ }^{38}$ Legislation over hospitality, instead of its provision was overlooked and no modification made in the Sarai Act 1867 and the Hotel and Lodging Houses Control Act 1950 saw some development. The period of 1960 to 1977, witnessed a development of tourism and hospitality in this country-though very slow in nature. While following this, various bodies of hospitality (e.g. Associated Hotels of Pakistan Ltd, in 1961) and tourism (e.g. Pakistan Tourism Development Corporation, PTDC in 1970) were created for catering needs and requirement of visitors, tourists and travelers. ${ }^{39}$ The creation of these bodies, indeed, acknowledged the prominence of hospitality: opening up avenues of investment and employment for private and government sector. Despite of all these, no appropriate legislation was made for hospitality and tourism. Moreover, no substantive steps had been taken for the Islamization of hospitality laws.

The deficiency, mentioned above, - continued for twenty-six (26) years i.e. till 1976, and Hotel and Restaurant Act $1976^{40}$, after a long time, came to the legal spot. This law suspended the previous Sarais Act 1867 and the Hotel and Lodging Houses Control Act 1950: served as the solitary hospitality law for demand and supply side of the hospitality industry. In addition, this law provided a base for "the Pakistan Hotels and Restaurants Rules, $1977^{\prime 41}$ in 1977. This new legislation, indeed, had a complete complainant with the modern hospitality practices at that time. The Act had very rich content over various aspects of hospitalities e.g. the licensing, management and controlling procedures for hotels and restaurants. The star classification (of hotels) from one star to five-star hotels was made in this new piece of legislation for informing the management and visitors of the criterion of hotel rating system. Moreover, the terms like "Guest" 42 ,"Hotel"43 and "Customer"44 were also elaborated in the same Act. Some social maxims, about offering hospitality to the guests, were introduced too; including, mainly,"Mehman ALLAH ki rehmat hotay hain"( Guests are blessing of Almighty Allah) ${ }^{45}$ and "Jis gar main mehman ay, us gar main barkat hti hai (The home where guests visits, there the prosperity comes) ${ }^{46}$ and etc. These maxims supported, the rich traditional approach, followed by the inhabitants of Pakistan.

\section{Hospitality in Islamic Law: A Historical Approach:}

The history of hospitality in Islam possibly goes back to Hazrat Ibrahim (AW); a prophet equally valued and shared by Christianity and Islam. ${ }^{47} \mathrm{He}$ had been quoted a giver of high respect to the guests, on various occasions in Bible and Qurān as "It is Abraham who responds as a host to three visitors, feeding them and giving them shelter, unaware that they were angels in guise" ${ }^{\text {48 }}$. A verse of the holy Qurān, while showing his generosity for guests, explains

"Has there reached you the story of the honored guests of Abraham?

When they entered upon him and said, [We greet you with] peace. 'He 
answered, '[And upon you] peace, [you are] a people unknown. 'Then he went to his family and came with a fat [roasted] calf and placed it near them". 49

In Arabian Peninsula, offering hospitality to the passing by travelers, as per the historian, was considered of central importance Owing to this fact some scholars went on saying, "The virtue seems an ineluctable product of the landscape... to refuse a man refreshment in such a place is to let him die, to threaten the open handedness nomadic people must depend on to survive". . ${ }^{50}$ Moreover, offering generosity to visitors/guests was source of passion for Arabian society. While advocating the same Toshihiko Izutsu cited rightly,

"For a pagan Arab, charity was not simply a natural manifestation of his feeling of tribal solidarity, for very often it extended beyond the members of his own tribe to the strangers who happened to be there" 51 While quoting Legendary Arab poet $\mathrm{Ha}^{-} \mathrm{tim}^{52}$, Ibn 'Abd Rabbih argued as

"Kindle the fire for the night is severely cold And the wind is gusty and biting, $O$ kindler. Perhaps your fire will be seen by a passer-by;

If it will bring a guest to me, you will be free." 53

Divine teachings of Holy Qurān and Hadīth adjudicated respect of the visitors, traveler and guests as an obligation. In this regard, for instance, the Holy Qurān stated,

"They ask you, [O Muhammad], what they should spend. Say,

'Whatever you spend of good is [to be] for parents and relatives and

orphans and the needy and the traveler. And whatever you do of goodindeed God knows of it". ${ }^{54}$.

Imām Tabarī, a renowned interpreter of the Holy Qurān, derived an individual's obligation for giving respect to the traveler and visitors. ${ }^{55}$ The Prophet (SAW) had been reported to say

"Putting up a guest for one night is obligatory. If you find a guest at your door in the morning, then this (hospitality) is (like) a debt that (the host) you owe him. If he(the guest) wants, he may request it, and if he wants, he may leave it". 56

This Hadìth, and many others, declare guests' care as a religious obligation. Ibn Battuta, a famous Muslim travel enthusiast and explorer ${ }^{57}$, had testified the Muslim hospitality, arguing that travelers were welcomed and entertained at hospices and rest houses. ${ }^{58}$ The Islamic hospitality associated with the pilgrimage (Hajj and Umra) could be cited as another typical example. ${ }^{59}$

Imam Ghazāli $\bar{I}$, a classical Muslim jurist, too, had discussed the importance of guests, as per Islamic law, with minute details. ${ }^{60}$ Moreover, compulsion on the host (for the guest) had argued as,

"The Emissary of God(may God bless him and grant him peace) said, 'Do not go out of your way for a guest that you will come to dislike him, for he who dislikes a guest dislikes God, and he who has disliked 
God, God has disliked him. ' He said, 'There is no good in someone who is not hospitable' ${ }^{61}$

This interpretation, about the ethical obligations on the host, had acknowledge as part of faith for Muslims. In addition, spending on wayfarers and travelers had characterized as generosity . In this connection, $\mathrm{Al}$-Jāiz went on saying as "...A generous man is either reliant upon or has better expectations of ALLAH. In every circumstances he is closer to one trusting in ALLAH and more sympathetic to one of that kind". ${ }^{62}$ Imam GhazālI, while having this approach in mind, emphasized as

"A man ought not to decline [an invitation] because of distance or because of the host's poverty or lack of social standing. A distance that can normally be endured should not cause one to abstain. This is why it is said in the Torah or one of the sacred books, 'Walk a mile to visit a sick person, two miles to take part in a funeral, three miles to accept an invitation and four miles to visit a brother in God.' Precedence was given to accepting an invitation and paying a visit because through these one fulfills the right of the living, who are more deserving than the dead." 63 .

Patience and steadfastness had been made obligatory on the host while serving the guests. While elaborating the story of Ibrahim Bin Adham, Mona said:

"Ibrahim ibn Adham once brought plenty of food to his table and Sufyan [al-Thawri] said to him, 'O Abu Ishaq, do you not fear this is extravagant?' Ibrahim replied, 'There is no extravagance in food unless the intention is to be extravagant, abundant provision would [then] be an affectation. 'Ibn Mas'ud said, 'We have been forbidden to accept the invitation of someone who boasts about his food.' A group of Companions disliked eating food that had been boasted about" 64 .

Like obligations on host, Islamic law had put certain obligations on the guest too. Khwaja Hasan Nizami(1873-1955) had elaborated this as,

"When I intend to visit someone I inform my host eight days beforehand. I tell him that I will arrive at such and such a time and that I will have my servant with me, that I don't eat rice and don't drink tea, and that I shall bring my bedding with me and stay only one night. And I expect anyone who wants to stay with me to do likewise. That is what courtesy means or in other words 'behaving like a gentleman". 65

\section{History of Hospitality Laws in South Asian Countries - Commonalities:}

Legislative development, related to hospitality, over the time in the countries of South Asia, shared s resembled scenarios. Pakistan and Bangladesh, (former West and East Pakistan respectively, till 1971), for instance, were the most prominent ones in this connection; having the Sarai ${ }^{66}$ Act 1867 in their corresponding legal spectrum till 1976 in Pakistan and $1982^{67}$ in Bangladesh. Bengalese pace was, however, quite better than of Pakistan as they legislated the Bangladesh Hotel and Restaurant 
Ordinance, 1982 within the eleven years of their separation from the Pakistan. Pakistan, on the other hand, replaced the Sarai Act of 1867 with the Hotel and Restaurant Act 1976 of Pakistan Of course, the Republic of Bangladesh managed to formulate hospitality law; considering the global advancement while cashing the opportunity. In depth analysis of that law, however, led to the conclusion that courtesies of the Sarai Act had been acquired, ironically, in the newly formed 'the Hotel and Restaurant Ordinance, 1982'. In addition, maxims, typically the having religious origin, were kept intact at socio-legal level. For instance, Mehman ALLAH ki rehmat hotay hain (Guests are blessing of Almighty Allah) and "Jis gar main mehman ay, us gar main barkat hti hai (The home where guests visits, prosperity comes) and etc. had been emphasized too much the case of Pakistan, in terms of these maxims, was not different.

Countries like India and Nepal, on the other hand, also shared some similarities over the subject of history of hospitality laws, their legislation, development, implementation etc. .Prevailed reason behind that might be the same religious, geographical contexts and inter-connectedness of political dependability over each other. ${ }^{68}$ Both these countries progressed in the legal predicament simultaneously - a very rare phenomenon. However, here in this case, Nepal showed, comparatively, swift stride towards the developing hospitality law i.e. The Hotel, Lodge, Restaurant, Bar and Tourists Guide Rules, $1981^{69}$. In India, on the other hand, retained the Sarai Act 1867 with moderate and contextual modifications. Nepalese pace was quite a need of time, addressed the problems of incoming visitors and travelers to this country, having highest summit (Mount Everest). Additionally, the similar dominant religion (Hinduism) and political connectivity among these two countries, led to alike social proverbs, extending the guests their due respect and put, at the same time, religious compulsions on the people as hosts.

Common aspects, between Pakistan and India, on the legal history of hospitality, stood on the Sarai Act 1867 owing to the fact that this act had remained as a sole legal source of hospitality for a long time, both at strategic and operational level, in Pakistan and India. Common legal aspects, because of this reason, do exist between these two countries. Many terms, related to hospitality, were having the same meaning in both countries. These terms included, not exhaustively, guests, sarai, hotel, sarai-keeper etc. Besides, these two countries, once remained under the administrative loop of Indian Sub- continent, had shared same cultural version of hospitality; could be rightly called amalgamation of various religious and ethnic entities of the sub-continent. ${ }^{70}$

On religious grounds, there existed some similarities in terms of hospitality's rules between Hinduism and Islam. For instance, ascribing the services to the guests had considered a sacred responsibility. These religions, equally urged for hospitality services, predominantly, by means of teachings, narratives and social-cum-religious maxims, irrespective of ideological variations in other religious aspects.

Social and Institutional implications of Research: 
A Social system, no doubt, entails the set of rules in the best interest of public at large. Discrimination on lingual, racial, ethnical basis disrupts this system. The current study had described commonalities among various countries of South Asia in their approach towards hospitality. While having such characteristics, social consensus and unified harmony could be reach through this study. It would also create awareness among the general masses regarding the hospitality laws' development in the South Asian regions. Hence, social cohesion and solidarity over the hospitality could be created through this and other similar studies. Benefit could also be taken from the current study at formal level. Legal institutions, for example, could incorporate this historical perspective of hospitality in their legislative mechanism and structure. Moreover,the existing hospitality laws could be updated in the light of the same study. In addition, the religious aspects discussed herein, could be beneficial for religious tourism. In case of Pakistan, being an Islamic country, the Islamic hospitality guidelines, teachings and their interpretations could be included in the hospitality and tourism laws.

\section{Academic implications of Research:}

The current research is an attempt to elaborate the brilliant historical development of hospitality laws in South Asian countries. On the same way, the hospitality laws' development is also discussed from the historical jurisprudence of Islamic law. It can be said, with solid arguments that more importance is given to hospitality laws in Islamic law comparative to other legal system. However, this fact is entirely ignored in the academia. While having such teachings in mind various courses and specific subjects can be included and offered in the curricula of hospitality and tourismoriented degrees. Also, this inclusion can be done in short skills development courses, diplomas and crash courses of hospitality; catering the hospitality through trained and well-acquainted human resource. Moreover, the current study is introductory in nature and, hence, leaving an open avenue for a minute study.

\section{Conclusion:}

From time immemorial, human beings are living in this world in a regularized way; subject to certain limitations and laws. Among these laws, hospitality laws are of worth importance. In case of South Asian countries, there has been existing homogeneity among them in terms of cultural and social values; instead of having diversity, predominantly, in the area of religion. On the subject of hospitality, these countries have constituted decorum for the guests; entrenched in their cultural, traditional and religious excerpts. While having such a common history of hospitality, the current study has embarked these three aspects from historical perspective. Analysis of cultural and traditional aspects confirms that a similar custom has been followed by these countries; facilitating the visitors, travelers, guests. Remaining under the rule of the Great Britain, most of these countries have used the same legal packages for dealing hospitality and other related issues. For instance, the Sarai Act 1867 has been remained a main hospitality law in Pakistan, Indian and Bangladesh for a long time. 
Because of these reasons, all these countries are having almost similar legal approach towards the hospitality and other related issues. However, this is not the sole reason behind such commonalities. Finding shows, for instance, that major religions of these countries i.e. Hinduism, Islam and Buddhism have the same teachings for hospitality. Owing to this fact, all these countries have inculcated such religious guidelines in their corresponding legal spectrum. . Being a complete code of life, Islamic law, on the other hand, offers a comprehensive guideline for the protection of tourists' lives and properties. The classical Muslim jurists have elaborated these guidelines with minute details; urging the Islamic state to include all these in hospitality laws. Pakistan, being an ideological state, have worked hard to legislate hospitality laws (and even to implement) in the light of these settled golden principle. Study reflects, with solid arguments, that still many work is remaining to be done.

\section{References:}

${ }^{1}$ Qurān,05:03The English translation of the Holy Qurān is adopted from Abdullah Yousaf Ali. See for further details Abdullah Yousaf Ali, The Holy Qurān (King Fahd Holy Qurān Printing Complex) 1987

2 Qurān, 04:36.

${ }^{3}$ Regarding "Dayf", the original text of the Holy Qurān flows as"And tell them about the guests of Abraham"Qurān, 11:51, Also see Qurān, 15:68 where the original text flows as "Indeed these are my guests, so do not shame me".

${ }^{4}$ Shawkānī, Nayl al-Awtār, (Dār Ehiā al-Tourath al- Arabī, $1^{\text {st }}$ Edition.2001).

${ }^{5} \mathrm{Abū}$ Bakr ibn Mas'ūd al-Kāsānī, Bādā'i 'al-Sanā' 'i ',1 $1^{\text {st }}$ Edition, (Beirut: Dār al-Fikr Labnan, 1996).

${ }^{6}$ Ibn Qudāmah al-Maqdisī, Al-Kafì, $5^{\text {th }}$ Edition, (Beirut: Al-Maktab al-Islāmī̄, 1988).

${ }^{7}$ Abū al-Walīd Muhammad ibn Ahmad ibn Rushd, Bidāyt al-Mujtahid wa Nihāyat al-Muqtasid, Vol. 2, 1st Edition. (Beirut: Dār al-Fikr Labnan, 2003).

${ }^{8}$ Abū Bakar Muhammad ibn Abī Sahal Sarakhsī, Al-Mabsūt, (Beriut: Dar-Ehyā al-Turāth, 2002).

${ }^{9}$ Ibn 'Ābidīn, Radd al-Muhtār, vol. 6, (Beirut: Dār al-Fikr, 2005).

${ }^{10}$ Act No.LXXXI of 1976 Pakistanis also termed as "The Pakistan Hotels and Restaurant Act, 1976".

${ }^{11}$ Objective Resolution is always considered, by the historian, as one of the most important documents, predominantly, in the constitutional history of Pakistan. Under the leadership of Liaquat Ali Khan, the document was passed by the first Constituent Assembly on 12th March,1949. It laid down the basic principles; which were supposed to be incorporated in all future constitutions. One could imagine the importance of such document from the fact that it was declared as a preamble for the constitutions of 1956, 1962 and 1973. After studying the document, profoundly, one could easily understand the very nature of it i.e. an amalgamation of Islamic and western political systems... Please see for further details http://historypak.com/objectives-resolution-1949/ ( accessed August 13, 2018)

${ }^{12}$ Mona Siddiqui, Hospitality and Islam, Welcoming in God's Name (London, Yale University, 2015).

${ }^{13}$ Marcus L Stephenson," Deciphering "Islamic hospitality": Developments, challenges and opportunities", Tourism Management 40(2014), 155-164.

14 "Islamic hospitality" a word used by Marcus L. Stephenson in his article "Deciphering "Islamic hospitality: Developments, challenges and opportunities" cited above, to describe the modern hospitality and its compliance with the Sharia in general and Islam in particular.

15 Toshihiko Izutsu, Ethno-Religious concepts in the Qur'an (Montreal \& Kingston, London \& Ithaca: McGill-Queen's University Press, 2002).

${ }^{16}$ Sanskrit is the ancient language of South Asia spoken, particularly, by the followers of Hinduism, Buddhism and Jainism.

${ }^{17}$ The English translation goes as "Be one to whom the mother is a God. Be one to whom the father is 
a God. Be one to whom the teacher is a God. Be one to whom the guest is a God". Please see for further details http:// translation.www.worldlingo.com ( accessed August 13, 2018)

18 Pratibh Budania, Hotel and Hospitality in India Through Ages, International Journal of Advanced Research and Development,3(01),2018, 994-999

${ }^{19}$ Walpola Rahula, What the Buddha Taught, Revised and Expanded Edition with Texts from Suttas and Dhammapad,(New York, Grove press,1974).

${ }^{20}$ Dharmashalas, used for "Charity Houses for travelers" translation adopted from : Pratibh Budania, Hotel and Hospitality in India Through Ages, International Journal of Advanced Research and Development,3(01),2018, 994-999

${ }^{21}$ Pratibh Budania, Hotel and Hospitality in India Through Ages, 3(01),2018, 995

22 Incredible India, is the logo for International Tourism campaign, launched in $2002 \ldots$ Please see for further details http://www.incredibleindia-tourism.org ( accessed August 13, 2018)

23 Stephen Ball, Susan Harner, Kevin Nield, Contemporary Issues of Hospitality and Tourism Management in China and India- Todays Dragon and Tigers(Oxford ,Elsevier,2007) 115.

24 Vinnie Jauhari, Competencies for a Carrier in Hospitality Industry: An Indian Perspective, International Journal of Contemporary Hospitality Management, 18(2), 2006

${ }^{25}$ Brijesh Thappa, Tourism in Nepal, Journal of Travel \&Tourism Marketing,15(2-3),2008,117-138.

${ }^{26}$ Ibid, 117

${ }^{27}$ Carolyn L. McMillan Kevin D. O'Gorman Andrew C. MacLaren, Commercial hospitality , A vehicle for the sustainable empowerment of Nepali women, International Journal of Contemporary Hospitality Management, 23(04), 2011, 463-478.

${ }^{28}$ Please see for further details of these Acts ... http:// www.lawcommission.gov.np (accessed August 13, 2018),

29 Article 1, of Constitution of Peoples Republic of Bangladesh, 1972, flows as "Bangladesh is a unitary, independent, sovereign Republic to be known as the People's Republic of Bangladesh".

30 Zia Ul Haq Howlader ,Bangladesh a land of Hospitality, The Daily Star , January 09, 2012 https://www.thedailystar.net/news-detail-217499 ( accessed August 11, 2018)

31 Article 2A, of the Constitution of People's Republic of Bangladesh, 1972, flows as "The state religion of the Republic is Islam, but other religions may be practiced in peace and harmony in the Republic".

${ }^{32}$ Hospitality in Islam is more inclined towards complimentary provision of hospitality products and services.

${ }^{33}$ Muhammad Ashraf Haronn, Fayyaz Ahmad and Maniruzzaman, Customer Hospitality: The Case of Fast Food Industry in Bangladesh, World Journal of Social Sciences, 3(6), 2013,88-104.

34 Bangladeshi Culture-Etiquette ... See for further details https://culturalatlas.sbs.com. ( accessed August 10, 2018)

${ }^{35}$ Zia Ul Haq Howlader ,Bangladesh a land of Hospitality, The Daily Star , January 09, 2012

36 "Sarai" means any building used for the shelter and accommodation of travelers"The Sarais Act 1867

${ }^{37}$ ACT NO. LXV OF 1950 also known as The Karachi Hotel and Lodging -Houses (Control Act),1950

38 The original text goes as, "Islam shall be state religion of Pakistan" ........ The Constitution of Pakistan, 1973, Article 2.

39 See for details ... https:// www.tourism.gov.pk( accessed September 12, 2018)

${ }^{40}$ Act No. LXXXI of 1976 Pakistan is also termed as "The Pakistan Hotels and Restaurant Act, 1976"

41 The Pakistan Hotels and Restaurants Act, 1976 (LXXXI of 1976), Section 29

42 "Guest" means a person who is in possession or enjoyment of accommodation provided to him on monetary basis"... See for further details ... The Pakistan Hotels and Restaurants Act, 1976.

43 "Hotel" means a lodging or boarding and lodging establishment with a minimum ten lettable rooms provided for tourists on monetary considerations, which conforms to any of the prescribed minimum criteria ".... See for further details...The Pakistan Hotels and Restaurants Act, 1976. 
44 "Customer" means a person availing facilities offered in restaurant on monetary considerations... See for further details...The Pakistan Hotels and Restaurants Act, 1976

45 In Pakistani society, the guests are considered as "blessings of ALLAH Almighty" and the hosts are expected to go beyond while serving them.

46 This maxim means that those homes where guests frequently visit, prosperity from the Almighty ALLAH is assured for them and vice versa. Because of this reason public at large in Pakistan welcomes facilitates and farewells guests.

${ }^{47}$ Mona Siddiqui, Hospitality and Islam, Welcoming in God's Name, 10.

48 See Genesis 18:1-16; See also Qurān 15:51-64; Qurān 51:24-34; Qurān 11:69-75.

${ }^{49}$ Qurān 51:24-30.

${ }^{50}$ Miriam Schulman and Amal Barkouki-Winter, 'The Extra Mile, 'Issues in Ethics.2:1, 2000; See also ... Silas Webster Allard, 'In the Shade of the Oaks of Mamre: Hospitality as a framework for political engagement between Christians and Muslims', Political Theology, 13:4, 2012, 414-24.

51 Toshihiko Izutsu, Ethico-religious Concepts in the Qurān,(Montreal: McGill- Queen's University Press), 2002, 76

${ }^{52}$ Ibn Abd Rabbih. The Unique Necklace, Vol. 1 Al-Iqd al- Farid... Translated by Issa J Boulatta... (Reading, Garnet Publishing), 2007.

${ }^{53}$ Ibid.

54 Qurān 2:215

${ }^{55}$ Muhammad b. Jar̄̄r al-TabarĪ, Jāmi' al-Bayā an Ta 'wil āy al-Qur'ān, Beirut: Dar al- Fikr, 1990,117

56 Sunnan Ibn Majah, Book of Etiquettes (Darusslam), Vol 5, Book 33, Hadith 3677.

${ }^{57}$ Ross E Dunn. The Adventures of Ibn Battuta: A Muslim Traveler of the Fourteenth Century, With a New Preface. (University of California Press, 2012).

${ }^{58}$ Ibn Battuta, Travels in Asia and Africa:1325-1354(London, Routledge, 2004)

59 Marcus L Stephenson, "Deciphering Islamic hospitality: Developments ,challenges and opportunities", Tourism Management 40(2014), 156

${ }^{60}$ Mona Siddiqui, Hospitality and Islam, Welcoming in God's Name, 112.

${ }^{61} \mathrm{Al}$ - Ghazālì, On the Manners relating to Eating, Kitāb ādāb al-akl, Book XI of The Revival of the Religious Sciences, Ih. yā' 'ulüm al-dīn...Translated by..., Denys Johnson Davies, (Cambridge: Islamic Texts Society, 2000).

62 Al-Jāhiz, the Book of Misers, Al-Bukhalā,'... Translated by R.B. Serjeant... (Reading: Garnet Publishing), 1997, 2

${ }^{63}$ Adi Setia, The Book of the Proprieties of Earning and Living (Kuala Lampur, IBFIM,2013).

${ }^{64}$ Mona Siddique, Hospitality and Islam, Welcoming in God's Name, 108.

${ }^{65}$ Ralph Russel, ed. An Anthology of Urdu Literature. Carcanet, 1999.

${ }^{66}$ The original text "Sarai" means any building used for the shelter and accommodation of travelers, and includes, in any case in which only part of a building is used as a Sarai, the part so used of such building. It also includes a purao so far as the provisions of this Act are applicable thereto. The Sarai Act of 1867, Section.2

${ }^{67}$ Bangladesh Hotels and Restaurants Ordinance, 1982

${ }^{68}$ Girdhari Dahal, Foreign Relation of Nepal with China and India, Journal of Political Science, 18, 2018, 46-61.

${ }^{69}$ Hotel, Lodge, Restaurant, Bar and Tourist Guide Rules, Nepal, 2038 (1981).

${ }^{70}$ Dietrich Reetz, Ethnic and religious identities in colonial India (1920s-1930s): a conceptual debate, Contemporary South Asia, 2(2), 1993, 109-122

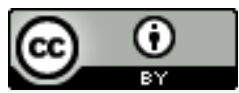

This work is licensed under a Creative Commons Attribution 4.0 International License. 